\title{
UTWÓR LITERACKI JAKO DZIEŁO SZTUKI \\ (NA PODSTAWIE WYBRANYCH DYSKUSJI PUBLICZNYCH, ODNOTOWANYCH W POLSKICH CZASOPISMACH PO 1989 ROKU)*
}

\section{WPROWADZENIE}

W „Twórczości” z 1969 r. wydrukowany został tekst Janusza Połomskiego Poezja a filozofia, który nie spotkał się - z tego co mi wiadomo - z jakimś wyrazistszym przyjęciem, wtopił się w obfitość produkcji piśmienniczej swojego czasu, a po trzydziestu niemal latach odnotowują go jedynie bibliografie recepcji Rilkego w Polsce jako jeden z wielu komentarzy do austriackiego poety; komentarzy wyrastających z niemieckiej tradycji hermeneutycznej.

A przecież był ten szkic, pośrednio, chociaż nie tylko, intelektualnie obowiązującym, odcinającym się od innych głosem w sprawie realnie rozpoznawanej elitarności poezji (sztuki słowa); taka postawa demonstrowana była przez autora w każdym niemal zdaniu, które przerastało polonistyczne „drobienie” poznawczych kroków, wła-

Szkic ten nie jest: rozprawą na tematy estetyczne, ostatecznym werdyktem dotyczącym stanu współczesnej świadomości dzieła sztuki, systematyczną prezentacją wszystkich, czy nawet większości głosów, odnoszących się do sposobu obecności literatury jako sztuki słowa, które zaistniały „publicznie” (ze względów oczywistych byłoby to niemożliwe).

Jest natomiast wyrywkową, symptomatyczną próbą rozwiązania tytułowego problemu na podstawie ważniejszych, a uznaniowo wykorzystanych dyskusji; nie jest, mimo wszystko, rezultatem kapryśnych doborów sądów i ocen. Najważniejsze były dla mnie wypowiedzi potwierdzone intelektualnym i społecznym autorytetem rozmówców, a także ich utrwaloną obecnością w życiu publicznym.

Szkic powstał jako fragment grantu w Pracowni Literatury XX i XXI w. w IBL PAN. 
ściwe chyba rozczłonkowującym się i coraz bardziej specyfikującym swój obszar badawczy, dyscyplinom humanistycznym.

Pisał wówczas Połomski:

Po grecku poezja oznacza pewne zachowanie bytu ludzkiego, „tworzenie"; poezja jako poiesis to tworzenie w sensie powoływania do istnienia tego, co dotychczas nie istniało w mowie, wypowiadanie dotychczas niewypowiedzianego - określenie to zabrzmieć może jako banalny ogólnik, ale sens ma zgoła niebanalny, jeżeli, próbując go zrozumieć, odróżni się mowę od języka i słowo od terminów, tak jak za Platonem Grecy i Rilke. Tak jak istnieje klasyczna koncepcja poezji - ją wypowiada wstępnie właśnie powyższe określenie. Warto ją zachować. Pozwala ono oddzielić poezję od niepoezji, a więc od całej mnogości wierszy ruchu lite ra cki e go (podkr. B.K.-Ch), oraz dojść do tego, co najbardziej własne u każdego autentycznego poety ${ }^{1}$.

Nawet jeśli niewielkie fragmenty tego cytatu, wydawałoby się, kierują w stronę tej estetycznej i literaturoznawczej hermeneutyki, która w dyskursie badawczym i krytycznym już się nieco zużyła, to generalnie ta wypowiedź, ustawiając opozycję ,sztuka poezji - ruch literacki”, stwarza niezwyczajną aksjologiczną aurę wokół faktu dzieła sztuki słowa i wobec procesu twórczego, za którym stoi, określona przez nobilitujące zdania, osoba.

Można powiedzieć: modernistyczny rzut i kontynuacja takiego zamysłu; modernistyczny poeta, którego twórczość jest komentowana.

Czy nie dałoby się całej tej sytuacji sprowadzić do przykładu przywoływanego przez samego Rilkego (w nieco innych oczywiście kontekstach), kiedy poeta pisząc list do Balthusa relacjonuje, jak to August Rodin opowiadał mu kiedyś, że czytając $O$ naśladowaniu Chrystusa zamiast każdego słowa „Bóg” wstawiał „Rzeźba”? Maksymalizm zapewne wyjaśnia tu jakość i rangę dzieła, maksymalizm zajmuje również ważne miejsce w próbach definiowania modernizmu, ale modernizm nie wyjaśnia do końca ani liryki autora Sonetów do Orfeusza, ani

\footnotetext{
Janusz Połomski, Poezja i filozofia, „Twórczość” 1969, z. 9, s. 72.

2 Rainer Maria Rilke, Listy do mtodego malarza Balthusa (Schloss Berg-am-Irchel, kanton zuryski, 24 listopada 1920), ,Zeszyty Literackie” 1998, nr 64, s. 43.
} 
tonacji szkicu Janusza Połomskiego, który sięgając do Platona, faktycznie, jak wynika z całości fragmentu (zamierzanej wówczas przez autora książki Poezja i filozofia), widzi twórczość Rilkego (zresztą analogicznie do pisarstwa Heideggera na polu filozofii), jako fenomenalny (jedyny, szczytowy) punkt rozwoju poezji w dziejach; w nim krystalizują się i stają uchwytne cechy poezji najdoskonalszej w ogóle - czy po prostu poezji w najważniejszym sensie tego wyrażenia. Można powiedzieć, że w szkicu Poezja i filozofia, znaczeniowo nadzwyczajnie gęstym, konsekwentnym i logicznym, uchwycona została w swoim konkretnym kształcie bezwzględna wartość sztuki lirycznej, przejawiająca się przede wszystkim w specjalnym ukonstytuowaniu języka, specyfice ekspansji poznawczej w tajemnice egzystencji, "olśniewającym rozumieniu tego, czego się dotąd nie rozumiało" tożsamości słowa poetyckiego z rzeczywistością (,z bytem”).

Poezja pierwotnie to możliwość ontyczna bytu ludzkiego, z realizacji której powstają poetyckie dzieła ${ }^{4}$.

Podstawowy i probierczy okazuje się też fakt, że taki ton prowadzenia myśli o poezji - sztuce słowa, zdarzył się tutaj w związku z twórczością Rilkego, który wyznaczył (mniej czy bardziej podskórnie) jakieś „orientacje” w życiu literackim późniejszych dziesięcioleci, również publiczne dyskusje samych poetów; tych obecnych w ,ruchu literackim" i być może również niewielu spoza. Znakomitą część tych zjawisk prześledziła Katarzyna Kuczyńska-Koschany w książce Rilke poetów polskich ${ }^{5}$ w której na pewno idzie o coś więcej niż tylko recepcja, a może właśnie tu rysuje się jakiś ważny zrąb problemu: pytania, co stało się z rozumieniem utworu literackiego jako dzieła sztuki? Co się właściwie dzieje współcześnie z tą formułą i czy to, co się dzieje, dotyczy samej formuły (języka), czy też czegoś, co kryje się za tą formułą rzeczywiście?

Próby ochrzczenia kilku konferencji naukowych przy pomocy słowa „piękno” (np. „Piękno wieku XIX”, „Piękno Słowackiego”), które

\footnotetext{
3 Janusz Połomski, dz. cyt., s. 79.

4 Tamże, s. 72.

5 Katarzyna Kuczyńska-Koschany, Rilke poetów polskich, Wrocław 2004.
} 
obowiązywało od zawsze jako podstawowa kwalifikacja dzieła sztuki, nie spotkały się ze specjalnym aplauzem środowiska. Zresztą sami organizatorzy poniekąd zdawali sobie z tego sprawę (nawet jeśli tej kategorii próbowali ostatecznie bronić). Erozji bowiem ulegają najszybciej słowa sygnujące rzeczywistość w jakiś sposób dla człowieka najważniejszą, albo tę jej część, wokół której wrażliwość wzniosłaby najchętniej ochronny mur milczenia. Wydaje się, że podobny los dzielą inne, naczelne kategorie niegdysiejszej estetyki. Weryfikuje je współczesna wrażliwość pojedynczego człowieka i ostatecznie wrażliwość społeczna. Ta zaś najwyraźniej odbija się w publicznych rozmowach, medialnej wymianie zdań, niewerbalizowanych często kryteriach osądów.

Stąd taki punkt wyjścia: prawie niezauważony szkic Janusza Połomskiego, polska i szeroka recepcja jednego z największych poetów (por. ostatnie rozdziały książki K. Kuczyńskiej-Koschany) po dzień dzisiejszy ustanawiająca najwyższy pułap oczekiwań wobec tekstu literackiego (poetyckiego), pułap przekraczający chyba roszczenia wyznaczane przez bieżący „,ruch literacki”; nie chcę twierdzić, że pułap jedyny, ale znamienny; jeden biegun współczesnego myślenia - mniej ofensywny, może chwilami zamierający, chociaż ciagle obecny. Poza dyskusjami akademickimi, które - miewa się takie wrażenie - rozstrzygnęły już wszystko ${ }^{6}$.

Formuła „dzieło sztuki” jest określeniem wartościującym. Zakłada rzeczywistość zorganizowaną tak, że szczególność tej organizacji realizuje, jak nazwał to Janusz Sławiński, „zobowiązanie estetyczne” (strukturalny charakter, wyrazistość organizacji materiału językowego, fikcyjny charakter świata przedstawionego, oryginalność rozwiązania artystycznego) ${ }^{7}$.

Ustalenia Janusza Sławińskiego mają charakter „mianownikujący”, w pewnym więc sensie - minimalizujący; nieco bardziej wartościującą definicję dzieła sztuki wyprowadzić można z klasyka współczesnej

\footnotetext{
6 Zob. np. Grzegorz Dziamski, Postmodernizm wobec kryzysu estetyki wspólczesnej, Poznań 1996.

7 Janusz Sławiński, Dzieło literackie, hasło w: Michał Głowiński, Teresa Kostkiewiczowa, Aleksandra Okopień-Sławińska, J. Sławiński, Słownik terminów literackich, pod red. J. Sławińskiego, wyd. 3, poszerz. i popr., Wrocław 1998.
} 


\section{UTWÓR LITERACKI JAKO DZIEŁO SZTUKI}

estetyki, Romana Ingardena, w którego pismach pojawia się chociażby sprawa tzw. jakości metafizycznych, a która odżyła w niedawnej dyskusji „Znaku” (Szukajac pocieszenia. O sztuce, $\mathrm{nr}$ 12, 2002).

Ale... formuła ,jakości metafizycznych”, przynajmniej drugi jej człon, sytuuje się nieco po stronie słów w języku powszechnym dewaluujących się, zużytych, nie przyjmowanych jednoznacznie, chociaż swą wartość w obrębie nauk szczegółowych zachowuje.

Spróbujmy odnaleźć drugi biegun stanu społecznej świadomości dzieła sztuki, drugi biegun wobec zaznaczonego wcześniej, sygnowanego nazwiskiem Rilkego, miejsca. Ta biegunowość przejawia się np. w wychwyceniu i opisaniu mechanizmów, zasad, rządzących poezją współczesną w szkicu Lidii Burskiej Miasto i poezja. Tekst ten, ze względu na swoją probierczość skumulowanych obserwacji i wyrazistość diagnozy krytyka posiada dużą wartość suwerennego głosu w dyskusji na temat najbardziej współczesnej i również najbardziej eksponowanej w mediach i publicznej świadomości utworu literackiego jako dzieła sztuki.

W konfiguracji problemów, o których pisze autorka, na pewno nie mieści się formuła takiego dzieła, ani w pewnym sensie to, co stanowi jej zawartość, wyznaczona, nawet możliwie szeroko, synchronizującymi wytycznymi Janusza Sławińskiego czy Romana Ingardena.

Relacjonuje Lidia Burska w pierwszym rzędzie fantomowy (nierzeczywisty) typ kultury, mówi o apoteozie ,przygodności, wolności i dowolności istnienia", objawiających się w manifestach poetów, pomieszaniu języków wreszcie:

Dziś problemem poezji jest pomieszanie i zrównanie wszystkich języków symbolicznych przeszłości i teraźniejszości, nieustanne szumy, zlepy, ciągi, które są zaprzeczeniem ciągłości i służą raczej jako „oznakowanie” obszarów wyłączonych i przyjętych na własność. Dawne języki tradycji także nie wyznaczają już przestrzeni wspólnej, a jedynie emblematy i granice światów wyodrębnionych i przywłaszczonych przez użytkowników różnych idei, religii, mów, stylów życia, wzorców kultury etc. ${ }^{8}$

8 Lidia Burska, Miasto i poezja, w: Co dalej literaturo? Jak zmienia się wspótcześnie pojęcie i sytuacja literatury, praca zbiorowa pod red. Aliny Brodzkiej-Wald, Hanny Gosk i Andrzeja Wernera, Warszawa 2008, s. 271. 
To, co Burska odnajduje, krytycznie zreszta, ale jako przeciwstawienie dominujących $\mathrm{w}$ jej obserwacjach trendów, zjawiska poetyckie: Robert Tekieli, Wojciech Wencel, przy całym szacunku dla ich postaw, wielką poezją czy wielką twórczością literacką raczej nie jest; przeciwstawienie niczego więc nie wyjaśnia, niewiele wnosi do moich poszukiwań.

Zresztą generalnie, ludzie i zjawiska, o których mówi się w szkicu Lidii Burskiej, są raczej symptomatyczne, bardziej znamienne dla czasu, niżeli arcydzielne. To, że Tekieli czy Wencel upodobali sobie w sferze sacrum, metafizyce, klasycznej formie wiersza, nie zmienia faktu, że ich głosy mieszczą się w obrębie i ostatecznie, jakiejś debaty literackiej czy kulturowej, próby sił określonego myślenia (propozycji) estetycznego, niekoniecznie wielkich wydarzeń z historii sztuki słowa. Zresztą tak rozumiem głos Lidii Burskiej: jako znakomitą pisarsko informację na temat statusu tekstu literackiego najnowszej współczesności.

Co wynika z niej pośrednio, trochę wbrew oszałamiającej wizji tempa, zmiany, migotliwości, bezhieratyczności i bezhierarchiczności, amorficzności, wszechogarniającej tendencji do błyszczącego ekspresywnie ujednolicenia?

Autorka Miasta i poezji dotykając zjawisk „ruchu literackiego” i zbliżając do niego soczewkę jest poniekąd zmuszona do mówienia o „fantomowości” kultury, „,nieprzerwanej fikcyjności” otoczenia, odczuwaniu rzeczywistości, a często także własnego ,ja" piszących, jako fragmentu owej fikcji. Ale jak się okaże, poeci szukają ,,wyjścia z rzeczywistości wytwarzanej i nieustannie reprodukowanej, ze świata doskonałych imitacji, w którym nie tylko zatraca się pamięć oryginału i ginie potrzeba obcowania $\mathrm{z}$ nim, ale także odrealnia się samo życie"

Nierzeczywistość, ,zona” sztuczności staje się postacią jedynie dostępnego świata; jego prawda jest również jedyną osiaggalną postacią prawdy. Obserwujemy tu pewne, spiętrzenie” sposobu widzenia tego świata przez prezentowane pokolenie (Sosnowski, Wiedemann); dostępna rzeczywistość staje się możliwością nowej realizacji arystote-

\footnotetext{
9 Tamże, s. 256.
} 
lesowskiej mimesis. U podstaw takiej sytuacji stoja, powiedziałabym, odwieczne zasady twórczych, artystycznych poszukiwań.

Burska mówi: „Interesują mnie twórcy, którzy odważnie wchodzą w nieuformowane życie miasta"; ależ tak, jest to niemal jedyny punkt wyjścia dla pisarza, poety; obserwacja danej rzeczywistości, doświadczanie jej, od dawna stanowi pierwszą i podstawową faze procesu twórczego. Tylko - kontynuuję wątek już poza myślą autorki Miasta i poezji - poeci pokolenia, o którym ona pisze, pozostają na poziomie odzwierciedlenia swojego miasta. Bo przecież i na przykład Joyce w Ulissesie również „odważnie wchodził w nieuformowane życie miasta”, ale jaką „konkluzję estetyczną” posiada to dzieło? „Miasto odbija się w twórczości poetów", jednak jest jakby za mało, w sensie dodatnim, przetworzone; poszczególne wizje czy propozycje nie posiadają tej nadwyżki, która czyni z nich osobny przedmiot estetyczny, co jest rezultatem zawsze jakiejś specjalnej organizacji, naddatkiem. Jak wiemy z historii sztuki, nawet w przypadku dzieł najbardziej realistycznych mamy z tą ,nadwyżką" (organizacją, porządkiem) zawsze do czynienia.

Jeśli zauważamy, idąc tropem autorki szkicu i wykorzystując jej obserwacje, mieszanie się w języku poetów „niskiego” z „wysokim”, „masowego" z ,elitarnym” (a Lidia Burska do tych spraw parokrotnie wraca), jeśli mówimy o postawie buntu, będącej rezultatem zachowań „w imię prawdy”, to doskonale wiemy, że nie są to zjawiska nowe, że podstawowym mechanizmem tworzenia dzieła romantycznego na przykład było tzw. obniżenie stylu, wprowadzanie do tekstu literackiego elementów „niskich” właśnie, potocznych. Natomiast bunt w naszych czasach koniecznie trzeba zobaczyć jako konwencję - bunt jest konwencją. Ta ostatnia dygresja wyraźnie prowadzi do konstatacji prawidłowości drogi - ustalonej dawno - do spełnienia dzieła sztuki (prawda, bunt, mieszanie stylów i form), która jednak nie zawsze i nie w każdych warunkach wiedzie do pozytywnych rezultatów.

Nie ulega jednak wątpliwości, że świadomość utworu literackiego - arcydzieła, podlegającego uchwytnym normom, utrwalonym jednak 
przez kolejne wieki, jest tu obecna - nawet jeśli przyjmiemy, że ścisła, literalna definicja dzieła sztuki ma charakter otwarty ${ }^{10}$.

Jeżeli w wypowiedziach dotyczących najbardziej charakterystycznych symptomów naszej współczesności literackiej mówi się o rozbijaniu form i norm, wszechobowiązującym czynniku destrukcji w imię odsłaniania autentycznego obszaru rzeczywistości, to faktycznie jest to mówienie o nowym dochodzeniu do nowej praw dy świata, chociaż prawda doświadczenia i prawda widzenia stają się znów, i niekoniecznie pośrednio, wartością, której wprost odmawia się racji bytu.

Wiersze będące obrazem zapamiętanych zdarzeń, rzeczy lub wzruszeń stają się epifaniami, bramą do niewyrażalnej prawdy, ,prześwitem” istnienia $^{11}$

- pisze Lidia Burska; przecież to artystyczne credo pisarzy i artystów modernistycznych, przedmodernistycznych i niemal każdego pokolenia tytanów sztuki, którym udało się po sobie nieco zostawić.

Wydawało się wcześniej, że te dwa bieguny, sygnowane nazwiskiem Połomskiego i Burskiej, posiadają swoje racje wyodrębnienia. Jeden z nich przekładał się na maksymalizm i elitaryzm, drugi - na minimalizm i pospolitą powszechność w rozpoznawaniu miejsca i roli dzieł sztuki literackiej. Można by jednak zapytać, czy ten drugi nie łączy się z koniecznie przylegającą do chaosu energia, natomiast ten maksymalistyczny i elitarny z pewną stagnacją (termin ten odnosi się do potencjalnego podłoża, z którego wyrasta dzieło sztuki) w oczekiwaniu na możliwie pozytywne rezultaty, może z pewną jednotorowością tych oczekiwań i z uporem odnoszącym sztukę (jej istotę) do możliwie zwiększającego swoją pełnię „człowieka egzystencjalnego”? ${ }^{12}$.

10 Grzegorz Dziamski, dz. cyt.

11 Lidia Burska, dz. cyt., s. 226.

12 Zob. Mikel Dufrenne, Phénoménologie de l'expérience esthétique, Paris 1953, t. 1-2. O jego estetyce, a zwłaszcza koncepcji odpowiedniości (podobieństwa) przedmiotu estetycznego do struktury osoby ludzkiej pisze Eugenia Basara-Lipiec w: Arcydzieło. Teoria i rzeczywistość, Warszawa 1997, s. 55-59. 
Wariant chaosu, „dysponujący” energia, pozbawiony jest, w takiej konfiguracji, kierunku, element destrukcji nie zostaje zrównoważony dążeniem do przezwyciężenia siebie samego. Energia wydaje się ślepa, więc rozproszona, rozpraszająca się ustawicznie ${ }^{13}$.

Narzucająca się konkluzja jest dość prosta, prowadzi do błahego nieco - jak może się wydawać - spostrzeżenia o „schizofreniczności”, rozdwojeniu myślenia o sztuce (utworze literackim jako dziele sztuki) jeśli nie uda się odnaleźć „terapeutycznych” działań scalających.

\section{ILUZORYCZNOŚĆ BIEGUNÓW? (W ZBLIŻENIU)}

Gdzieś w mglistych może okolicach tych biegunów sytuują się dwie dyskusje. Pierwsza, wspominana już, w „Znaku” w roku 2002 (numer grudniowy) i druga - w „Res Publice Nowej” (zima 2006).

Uczestnicy pierwszej $\mathrm{z}$ nich, generalnie, zmierzają w kierunku integralnej i pozytywnej (z punktu widzenia bardziej tradycyjnego) wizji sztuki, najczęściej prowadząc swoje myślenie w stronę elitarnego odsłaniania natury piękna, dyskutanci w „Res Publice Nowej” jakby w większym stopniu przyjmują to, co w sztuce właśnie się wydarza, przy czym to wydarzanie dotyczy przede wszystkim rzeczywistości medialnie dostępnej.

Dyskusję „Znaku” otwiera słowo Karola Tarnowskiego, krakowskiego filozofa, członka redakcji tego czasopisma. Tarnowski zakreśla szeroką perspektywę, wychodząc od sytuacji współczesnej filozofii, konstatując jej dzisiejszą postmetafizyczną kondycję. Porząakując w ten sposób - w zamierzeniu może: systematycznie (od: system) swoją wypowiedź, skazuje siebie na pewną nierównomierność wybrzmienia poszczególnych wątków i osądów. Wprowadzając za filozofem (Jean-Luc Marion) podział sztuki współczesnej na ,idolatryczną” i ,ikoniczną”, dokonuje aktu wartościującego, za którym stoi „wysokie" wybrzmienie dzieła sztuki, w pewnej opozycji do dziejącej się współczesności. Można zakwestionować taki punkt wyjścia „zagaja-

13 To problem doskonale znany „starej” estetyce, chociaż pojawiający się w rozmaitych myślowych konfiguracjach. 
cza" rozmowy, podobnie jak to zrobił Krystian Lupa, dopatrując się zalążków błędu w zbyt sztywnym przeniesieniu kryteriów epoki nieco starszej do czasu najbardziej współczesnego:

[...] materia dana poszczególnym okresom zostaje wyczerpana i owocuje krańcowymi wykwitami krystalizacji, które zawierają w sobie zarówno utajony kod genetyczny, jak i martwicze, rakowate struktury błędu. On w ostatnim okresie rozrasta się w postępie geometrycznym. To struktury starczej fazy epoki [...]

Epoki obecnej nie można w żadnej mierze uznać za „postmetafizyczna” (to tylko miraż widziany z wierzchołka usychającego drzewa). Jest nie tylko metafizyczna, ale, co więcej: jest epoką metafizycznego wrzenia. Tylko forma manifestacji treści metafizycznych, jaka dziś można zaobserwować, nie odpowiada starym kryteriom - a zatem przez pogrobowców minionej „metafizycznej epoki” treści te w ogóle nie są postrzegane jako metafizyczne. W tym cały szkopuł... ${ }^{14}$.

Czy uderzenie Lupy nie jest zbyt mocne, przesadzone? Może tak, może nie. Tarnowski formułując własne oczekiwanie wobec dzieła sztuki (także literackiej) wychodzi od dość elementarnych pytań i rozróżnień, pytań stawianych przez kilka przynajmniej wieków, poza konwencjami i modami, ale stawia je tak, jakby spodziewał się odpowiedzi na przewidzianym przez siebie torze. A przecież, pośród wielu innych, odnajdujemy w jego wypowiedzi obserwacje wiążące, umieszczone tu poza szeregiem jakiegokolwiek ,systemowego" odniesienia. Kiedy rzuca wspominane już przeze mnie hasło Ingardenowskich jakości metafizycznych, zwraca się ku określonemu zespołowi doświadczeń z obszaru recepcji sztuki, wszak estetyka Ingardena ma charakter na wskroś empiryczny. Formuła jakości metafizycznej ukuta została na drodze maksymalistycznie potraktowanego aktu twórczego i aktu odbioru, i - co Tarnowski nazywa faktem kluczowym - są one [jakości metafizyczne]:

14 Walka trwa. Z Tadeuszem Sobolewskim, Marta Tarabuła, Mieczysławem Tomaszewskim, Teresq Walas i Adamem Zagajewskim rozmawiaja Krystyna Kwaśniewska i Łukasz Tischner, „Znak”, grudzień (12) 2002, s. 60. 


\section{UTWÓR LITERACKI JAKO DZIEŁO SZTUKI}

nieoddzielne od ,jak" dzieła sztuki, a więc od jego uformowanej przez kunszt i wartości artystyczne konkretności: są względem dzieła tyleż transcendentne, co immanentne ${ }^{15}$.

I mówi dalej o ikoniczności sztuki (termin waloryzujący dodatnio) tych dzieł, „które nas wynoszą poprzez formę"16. Ty samym zwraca uwagę na podstawowy komponent definiowanego dzieła, który zdaje się zanikać jako rodzaj kryterium czy argumentu na udatność dzieła sztuki, a zwłaszcza sztuki literackiej; zanikać w sytuacjach rozmów na tematy estetyczne i ekspresji świadomości samych autorów.

Późniejsi rozmówcy (Tadeusz Sobolewski, Marta Tarabuła, Mieczysław Tomaszewski, Teresa Walas, Adam Zagajewski) niemal zgodnie kwestionują, chociaż z odmiennych punktów widzenia, myśl wyjściową Tarnowskiego o sztuce jako pocieszeniu. Zastanawia ta zgodność nieakceptacji. Pojęcie ,pocieszenia” poza tym, że wprowadza uchwytne paralele z niegdysiejszą filozofią, osłabia maksymalistyczne widzenie sztuki (sztuki słowa). Wprowadza jakiś półton, obniżenie tych funkcji, o których być może, nie nazywając ich wprost, myśleli dyskutanci.

Zagajewski nie godzi się, by rezultaty prac artysty były „tylko” pocieszeniem. W aluzji do Boecjusza, który swój traktat (O pocieszeniu jakie daje filozofia) pisał w więzieniu, widzi deprecjonującą dla sztuki analogię.

Nie chciałbym, żeby sztuka odnosiła się do kondycji ludzkiej tak samo, jak filozofia do sytuacji, w jakiej znalazł się Boecjusz, to znaczy - żeby była tylko pocieszeniem. Konsekwencje takiego ujmowania sztuki są bardzo poważne - oznaczałoby to, że cała egzystencja ludzka ma charakter więzienny, czarny. Moje zastrzeżenie nie ma natury ściśle terminologicznej, gdyż kryje się za nim pewna wizja losu człowieka ${ }^{17}$.

Zagajewski, gdzie indziej poeta „klasyczny”, broni tutaj wizji sztuki, która nie tyle byłaby „pocieszeniem”, ile odnosiła się istotnie

\footnotetext{
15 Karol Tarnowski, O pocieszeniu, jakie daje sztuka, „Znak”, grudzień (12) 2002, s. 23.

16 Tamże.

17 Walka trwa..., dz. cyt., s. 28.
} 
do życia człowieka i tej przestrzeni, która jest jego przekroczeniem (transcendowaniem) - ważnym, ,zbawiającym”. Tadeusz Sobolewski, wcześniej również nie akceptujący „pocieszenia” przez sztukę, mówi po prostu: „Mam poczucie, że ze sztuką można zejść nawet do piekła, ale sztuka nie zbawia"18. Jednak odnajduje takie funkcje sztuki (,wytwarzanie przeciwciał”), które niewątpliwie sytuują ją w dość wysokich rejonach ludzkich czynności.

$\mathrm{Na}$ „pocieszenie” nie godzi się również i między innymi Teresa Walas, Mieczysław Tomaszewski, wspominany Krystian Lupa... Niemal każdy z rozmówców zdaje się nie akceptować formuły umniejszającej w pewien sposób funkcje sztuki, być może zawężając rozumienie tego pojęcia. Na uwagę jednakże zasługuje jednomyślna niemal zgoda (niegodzącym się wyjątkiem jest tu Czesław Miłosz), niekoniecznie wprost, że wątek sztuki prowadzić należy wzwyż, zaś idea pocieszenia obniża jej wizerunek.

Ale wypowiedź Karola Tarnowskiego zdaje się mieć w pewien sposób niejednolity, przynajmniej pojęciowo, charakter. Myśl, która pojawia się tam również, o sztuce jako możliwości rozumienia losu, stoi w pewnej kolizji z ,pocieszeniem”, tak zdecydowanie zanegowanym przez polemistów. Należy jednak wziąć pod uwagę, że w formule o rozumieniu losu wraca proweniencja filozoficzna Tarnowskiego, ukształtowanie jego języka w obrębie fenomenologii.

Jaką terminologią posługują się rozmówcy i czy ta terminologia na coś wskazuje w kontekście wyjściowego tematu? Obserwujemy tu kolejny powrót w okolice Ingardenowskich jakości metafizycznych (wypowiedź Tomaszewskiego), a także formuły po Gombrowiczu skompromitowane: wielka sztuka zadziwia, zachwyca, przynosi radość. Powraca również sprawa przeżycia estetycznego jako momentu weryfikującego dzieło. Tadeusz Sobolewski, podkreślając wartość „kontaktu z rzeczywistością” w dziele spełnionym, w zasadzie ożywia, acz w nowy sposób starą kategorię Arystotelesowską. Zresztą kiedy mówi, wyjaśniając problematykę zła (,wielka sztuka wytwarza w nas przeciwciała"19), paradoksalnie (ponieważ pozornie odbie-

\footnotetext{
Tamże, s. 35.

19 Tamże, s. 30.
} 
ga od postaw pozostałych rozmówców, twierdząc, że sztuka nie zbawia) wywołuje myślowe rejony Arystotelesowskiej katharsis. Czym jednak różnią się ,jakości metafizyczne" Tarnowskiego od ewentualnej katharsis Sobolewskiego? Bo pierwotnie opis kategorii Ingardenowskiej z powodzeniem mieści się w szerokim polu tożsamości ze zjawiskiem opisanym przez Arystotelesa. Wydaje się, że Sobolewski w obręb swojej refleksji zagarnia jakby większy obszar doświadczeń współczesności, jakby posunął się nieco dalej w osłabianiu ostrej granicy między sztuką widzianą w szeregu wysokich konotacji i tą ,niższą". Na uwagę zasługuje fakt, że elementarna sytuacja problemowa, ostrze zagadnienia powraca do zamierzchłych, pierwotnych kodyfikacji. Podobnie rzecz wygląda w świetnej formule, autorstwa tegoż krytyka, której odsłona wzmocniona zostaje w wyrazie dzięki indywidualnemu doświadczeniu - właśnie z pogranicza estetycznego:

Kiedy odkrywam jaką́s wartość, czuję się bardziej wolny niż wtedy, kiedy mam jej odmówić2 ${ }^{20}$.

Można by powiedzieć, że jest to „echowe” nawiązanie do polskich estetyk dziewiętnastowiecznych i chyba nie tylko, ale jak wynika z kontekstu wypowiedzi, zrodziło się jakby od podstaw, prawem ciężaru nowej odsłony rzeczywistości własnego doświadczenia.

Charakterystyczne, że w rozmowie wracają (wprost i pośrednio) i utrwalają swoją pozycję niemalże wyznaczniki (komponenty) spełnionej sytuacji percepcji estetycznej, lub w jakiś sposób z nią powiązanej: więc po pierwsze kategoria piękna - jakby obowiązywała w dalszym ciagu, jakby nie doszło do istotnego naruszenia jej statusu na obszarze najbliższej współczesności; kontemplacja (tak ważna w estetyce od czasu Shaftesbury'ego); ikona (sztuka jako rodzaj wejścia, wtajemniczenia); konieczność (w odniesieniu do realizowanych wymogów konstrukcyjnych dzieła); prawda sztuki i fałsz sztuki (jej relacje z rzeczywistością doświadczoną przez człowieka).

Podsumujmy obserwacje.

$20 \quad$ Tamże, s. 39. 
Dyskusja sprawia nieco wrażenie wieży Babel; każdy z mówiących mimo pozornej wymiany zdań jest w najlepszym wypadku naznaczony własną, zindywidualizowaną wizją sztuki i swoim systemem pojęć, wyrastających z własnego doświadczenia estetycznego, jakby nieco hermetycznego wobec doświadczeń innych, w najgorszym zaś, jest $\mathrm{w}$ tym prywatnym systemie zamknięty. Ta rozmowa, wbrew początkowym założeniom, jakby wracała $\mathrm{w}$ rejony dywagacji bardziej na temat: czym jest sztuka (również sztuka literacka w ogóle), aniżeli: w jaki sposób zmienia się jej wizerunek dziś. Na pewno zaś prawie wszystkie przedstawione sądy skrywają w sobie kierunek ,do góry" w myśleniu o sztuce i sztuce słowa-jakby niewiele się zmieniło, chociaż sporadyczne sytuacje świadczące o tym, że jednak się zmieniło, bywają przywoływane.

Dyskusja zdradza tęsknotę za „wielką sztuką”, wielkimi dziełami literackimi również - i nadzieję, że może jednak wszystko pozostało jak dawniej-tak samo.

Ważne jest również to, że św ia d om ość tzw. formy, a więc s po sobu kształtowania dzieła, zaistniała dla rozmówców jako fakt niezbywalny.

Nad całością natomiast zdaje się dominować głos Wiesława Juszczaka, pomyślany przez redakcję jako dopełnienie dyskusji, zdecydowanie wyprowadzający całość obrazu tej rozmowy na aksjologiczne wyżyny, jeśli chodzi o rozumienie sztuki i jej natury ${ }^{21}$.

Interesujące, że wcześniejsi dyskutanci podkreślali wielokrotnie wagę zagadnień związanych z komunikacyjnym charakterem sztu$\mathrm{ki}$, ta jej cecha wymieniana była jako konstytuująca dzieło. Wiesław Juszczak już we wcześniejszych rozmowach ${ }^{22}$ i pracach wyklucza termin komunikacyjności z obszaru refleksji o sztuce. Dzieło sztuki pojmuje jako rzeczywistość przekraczającą sferę uwikłań społecznych. Na pytanie co jest, a co nie jest sztuką odpowiada:

\footnotetext{
${ }^{21}$ Na progu tajemnicy. Z Wiestawem Juszczakiem rozmawia Janusz Marciniak, „Znak”, dz. cyt.

22 Zob. Nietolerancja (rozmowa z Wiestawa Wierzchowska), przedruk w: Wiesław Juszczak, Fragmenty. Szkice z teorii i filozofii sztuki, Warszawa 1995.
} 


\section{UTWÓR LITERACKI JAKO DZIEŁO SZTUKI}

Dziś powszechne jest stanowisko, że nie możemy lub nie musimy odpowiadać na to pytanie wprost. Albo że nie ma na nie odpowiedzi. Taka forma eskapizmu (typowa dla krytyków i historyków sztuki) pogłębia zamęt w systemie kryteriów służących do porządkowania zjawisk, które wyznaczają obszar sztuki lub które do niego włączamy. Bo nie mamy wątpliwości, że obszar taki istnieje. [...]

Konsekwencją jest oczywiste - dla mnie - spostrzeżenie: stan tego, co obecnie uważa się za sztukę, nie pozwala na jej zdefiniowanie. Aby spróbować odpowiedzieć na pytanie, co jest sztuką, trzeba zapomnieć o tym, co dzieje się z nią teraz. Dzisiejsza kultura uczyniła ze sztuki zjawisko marginalne, a to, co uchodzi za sztukę, przeważnie ją tylko pozoruje. Owa pozorność odpycha. Trzeba poddać się temu „odepchnięciu”, by trafić na odległe miejsce, w którym odnaleźć można inne, autentyczne oblicze sztuki. Takie miejsca istnieją i dzisiaj, ale gubią się w ogólnym zamęcie.

[...] żeby określić istotę sztuki, należy stanąć na gruncie trwalszym niż ruchome piaski dzisiejszości. Takim punktem jest chronologiczny początek działań, które nazywamy sztuką. Bo każdy artysta, któremu nadałbym to miano bez wahania, stoi u początku sztuki. Tak, jak każdy wierzący stoi u początków religii, a każdy filozof u początków pytania, w jaki sposób istnieje to, co istnieje. W swej istocie wszystkie te dziedziny stanowią wspólnotę. Człowiek zostaje w nich postawiony poza cywilizacją-przed pytaniami pierwszymi i ostatecznymi zarazem ${ }^{23}$.

Utrzymując tonację myślenia radykalnego (i w pewien sposób zdroworozsądkowego) konkluduje:

[...] rozum tylko wtedy działa tak, jak działać powinien, kiedy zna granice swego działania. A granice te są bardzo wąskie i ogarniają zaledwie fragmenty rzeczywistości. Sztuka jest obnażaniem prawdy o tym, że rzeczywistość stanowi niezgłębioną tajemnicę. Im bardziej uzmysławia nam granice poznawalności, im bliżej podprowadza do progu tajemnicy, tym jest większa, bardziej autentyczna. [...] sztuka ma ukazywać ograniczenie zmysłowości poprzez to, co sensualne. Ma uzmysławiać granice poznania, a nie bredzić o niej niezbornie i nieodpowiedzialnie. Taki byłby początek roboczej definicji sztuki ${ }^{24}$.

\footnotetext{
23 Na progu tajemnicy..., dz. cyt., s. 76-77.
}

24 Tamże, s. 77. 
Cała wypowiedź Wiesława Juszczaka, a więc i fragmenty nie cytowane, po pierwsze - koresponduje $\mathrm{z}$ wypowiedzią, od której zaczęłam szkic, ujmującej rolę poezji (na przykładzie jedynym w swoim rodzaju twórczości Rilkego) jako pierwszego i najwyższego wtajemniczenia (wprowadzenia) w rzeczywistość; po drugie - godzi się ostatecznie z najbardziej klasycznymi definicjami sztuki (sztuki słowa) od najdawniejszych poczynając, poprzez narastające przez wieki wątki dopełniające, na XIX i XX wieku kończąc (krag promieniowania myśli i metody fenomenologicznej). Po trzecie: to niby usankcjonowane przez tradycję myślenie i definiowanie sztuki, przynajmniej skorelowane z maksymalistycznym widzeniem epok najodleglejszych i nieco bliższych, okazuje się wnikliwie dopatrzone i sformułowane na nowo, istotnie pogłębione.

Ciekawe, że wybitny znawca wyrafinowanego i genialnego malarstwa Witolda Wojtkiewicza, zapytany o normy arcydzielności literackiej wymienia m.in. Dostojewskiego, ale też Nad Niemnem Orzeszkowej, umiejętnie abstrahując od tego, co posłużyło (w przypadku tej pisarki) etykiecie tendencyjności i stopniowej kompromitacji tego pisarstwa przez idee, postawy i mody czasów najnowszych. W tym wypadku, jak pośrednio można wywnioskować, staje Juszczak wobec kryteriów pierwszych: nieredukowalnych pytań o człowieka i sposób (poziom) przetworzenia materii twórczej, projekt spójnej artystycznej całości, zrealizowanej w tej powieści.

Zapytany o relacje między kulturą i sztuką mówi:

Sztuka nie oddzieliła się od kultury. Kultura europejska poszła taką drogą rozwoju, która zepchnęła sztukę na margines. Stała się kulturą naukowa, zerwała z religią jako swym podstawowym źródłem. Nie absolutyzuję sztuki. Powiedziałbym raczej, że jest ona dążeniem absolutnym. Zakorzenionym w ludzkiej naturze usiłowaniem zbliżenia do tajemnicy Absolutu (w religijnym i ontologicznym sensie), próbą ukazania nieprzekraczalnego progu poznania rzeczy wyższych niż dostępne zmysłom i umysłowi ${ }^{25}$.

\footnotetext{
25 Tamże, s. 81.
} 
Mogłoby się wydawać, że jest to, na tle naszej współczesności, sąd odosobniony, nieprzyzwoicie ekstremalny, nakarmiony (z punktu widzenia tzw. postnowoczesności) mocno podejrzaną arbitralnością, drepczącą w stronę starych sposobów intelektualnego zniewolenia innych - jak to się przyjęło nazywać.

Mogłoby się również wydawać jeszcze inaczej; że Wiesław Juszczak prezentuje tu tzw. „metafizyczną koncepcję piękna”, która niekoniecznie podlega dyskusji na gruncie estetyki, ponieważ przenosi się samorzutnie na zupełnie inny obszar - teologiczno-metafizyczny ${ }^{26}$, ale wyrazistym kontrargumentem jest tu szczytowy moment estetyki wielekroć wspominanego Ingardena; teoria jakości metafizycznych wyprowadzona została przez filozofa z rzeczywistości doświadczenia estetycznego. Punktem wyjścia pozostała empiria. Podobnej terminologii używają też wcześniejsi, „empirycznie” nastawieni dyskutanci, odnosząc się do różnych sztuk, nie tylko literatury. Mówi np. Tadeusz Sobolewski: „Szukam kina, które prowadziłoby mnie ku tajemnicy znajdującej się poza obrębem sztuki"'27.

$\mathrm{Na}$ uwage jednakże zasługuje ranga, jaką pośrednio przyznało wypowiedzi Juszczaka redakcyjne gremium; wypowiedź wybitnego znawcy Wojtkiewicza i modernizmu w malarstwie, filozofa sztuki - została umieszczona jako zwieńczenie wcześniejszych rozmów, w których, obok już przywołanych, brali udział Zygmunt Kubiak, Czesław Miłosz, Jacek Sempoliński, Tomasz Stańko, Zbigniew Werpechowski, Adam Wiedemann.

Wiesław Juszczak był również uczestnikiem ważnej rozmowy, która miała miejsce nieco wcześniej („Gazeta Wyborcza”, 24-25 maja 1998 r.), charakteryzującej się mocnym spolaryzowaniem stanowisk.

Dyskusję, którą chciałabym zobaczyć jako drugi biegun (w odniesieniu do dyskusji w „Znaku”) zanotowała „Res Publica Nowa” (zima 2006). Uczestniczyli w niej: Lidia Burska, Andrzej Chłopecki, Małgo-

\footnotetext{
26 Por. Grzegorz Dziamski, dz. cyt., s. 21.
}

${ }_{27}$ Walka trwa..., dz. cyt., s. 35. 
rzata Dziewulska, Piotr Gruszczyński, Maria Poprzęcka, znów Adam Wiedemann i Marek Zaleski ${ }^{28}$. Swoista „biegunowość” tej rozmowy jest w dużym stopniu rezultatem małego dystansu do bulwersujących eksperymentów tzw. artystów, jakie miały miejsce ostatnio, a które z pełnym respektem dla wolności twórcy odebrane zostały przez media jako dzieła spełnione.

Wydaje się, że autorzy kolejnych wypowiedzi w rzeczywistości nowej sztuki, jako krytycy, tkwią bardzo mocno; mniejszy dystans do tych wydarzeń implikuje większą możliwość zrozumienia pojedynczej sytuacji, natomiast może utrudniać nieco generalizacje. Jednocześnie i tu bardzo wyraźnie ujawnione zostają tęsknoty za kryteriami dzieła rozumianego bardziej tradycyjnie. Krytycy mówią i myślą dość podobnie jak uczestnicy rozmowy w „Znaku”, ale ich postawy mają charakter bardziej nostalgiczno-akceptujący. Nawet jeśli nie ma tu pełnego, i w każdym przypadku, przyzwolenia, to można mówić o jakiejś, przyjmującej stan obecny, bezradności.

Marcel Duchamp, jako hasło wywoławcze, w rozmowach „Znaku” traktowany z dużym dystansem (mówiąc eufemistycznie), w dyskusji zanotowanej przez „Res Publicę Nową” potraktowany zostaje jako poważna cezura (Maria Poprzęcka). Nieco analogicznie przedstawia się sytuacja z problemem transgresji, chociaż fakt przekraczania granic w sztuce, w tej drugiej dyskusji został dokładniej skomentowany; rozpoznany jako zjawisko nienowe i zdewaluowane.

Biorąc pod uwagę bezpośrednie rezultaty dyskusji („,Res Publica Nowa") i jej puentę musimy odnotować wyrazisty cień na otwartej co prawda, ale względnie łączliwej z tradycją (również tą sprzed 1989 r.) wizji dzieła sztuki, w tym dzieła literackiego. Ale nawet fakt, że taka konkluzja ma charakter pesymistyczny (pesymizm będący wypadkową większości głosów), świadczy o oczekiwaniach krytyki odmiennych od tych sytuacji i przykładów, które właśnie są rozpatrywane przez zebranych.

A odnotowane zostają i opatrzone znakiem zapytania wydarzenia ekstremalne (np. decyzja aktora na sfilmowanie przewidywanej własnej śmierci - casus krakowskiego aktora Jerzego Nowaka - jako

28 Nie ma wyjścia, „Res Publica Nowa”, zima 2006. 
akt twórczy, skończone dzieło sztuki), prowadzące do pytania: czy to możliwe, by niczym nie ograniczony gest artysty (jeden gest; tu wraca postać Marcela Duchampa) stwarzał dzieło sztuki? Czy sytuacja skandalu publicznego (zawsze? najczęściej? rzadko?) sprzyja potwierdzeniu autentycznego zaistnienia aktu twórczego? Niektórzy z rozmówców zdają się przyjmować pesymistyczne rozpoznania, traktując je niezwykle serio; są przeświadczeni, że specyfika komentowanych wydarzeń jest właściwa dla naszej współczesności, ale też, najpewniej, taka utrwali się w przyszłości. Dzieło sztuki staje się czymś łatwy m, kaprysem wyobraźni, igraszka, nawet jeśli dotyczy problemu egzystencjalnie ważnego (poważnego). Jakby zapodział się gdzieś ten modernistyczny trud (Rodina, Rilkego), który prowadził do dzieła całkiem innego typu.

Ale nawet w rozmowie na temat „ekstremalnych” artystycznie sytuacji pojawiają się zdania (dotyczące niektórych z najnowszych dzieł):

[...] perfekcyjnie wykonana wielka praca, [dzieło] jest zamknięte, skończone, ma wielką siłę ekspresji, wyrasta z twórczego dialogu z tradycją... To są kryteria całkowicie tradycyjne ${ }^{29}$.

Więc jednak ten potencjalny model, który nie często bywa realizowany w praktyce, w umyśle obowiązuje, jest obecny...

Ale mówi się w dalszym ciągu o „kryzysie ontologicznym” dzieła sztuki (Chłopecki), o zanikaniu oryginalności na rzecz - w literaturze - samplowania i o „masowości bycia artystą”, albo pragnieniu, by nim zostać; o dążeniu wszelkich sztuk, by przekształcić się w towar. Czy zjawiska te przesądzają o rzeczywistej zmianie, zaniku świadomości społecznej istnienia czegoś takiego jak ,dzieło sztuki”?

W dalszym ciągu wydaje się, że niekoniecznie. Mówi Małgorzata Dziewulska o ,spłaszczaniu rzeczywistości dzieła obrabianego w skrócie przez media, koszmarnym języku komentarza"30, sama zaś

\footnotetext{
29 Tamże, s. 98.

30 Tamże, s. 101.
} 
rozmowa „Res Publiki Nowej” sprawia wrażenie jakby przytłoczonej medialnym wizerunkiem sztuki.

A przecież $\mathrm{w}$ epokach nieco wcześniejszych zamiast np. samplowania pojawiały się plagi niewyobrażalnego może dla naszych czasów naśladownictwa (np. sonetomania po sonetach Mickiewicza...), bycie artystą zaś już od jakiegoś czasu nobilituje - tak to wygląda w świadomości najszerszej, więc np. wielość tzw. poetów współcześnie również nie powinna dziwić. Tu dochodzi jedynie do dość ,naturalnego" zagęszczenia problemu. Warto natomiast zwrócić uwagę na kondycję krytyki, której sądy zdają się poddawać naporowi rzeczywistości (w dyskusji o kryteria pyta jedynie Marek Zaleski), chociaż nawet $\mathrm{w}$ przywoływanej rozmowie pojawiają się symbol (symbolizacja), metafora (metaforyzacja) jako pojęcia reprezentujące nadzwyczajność orga niza cji, decydującej o zaistnieniu suwerennej rzeczywistości dzieła artystycznego (literackiego).

Kiedy w dyskusji „Znaku” (z 2002 r.) Tarnowski odwoływał się do Ingardenowskich jakości metafizycznych, podkreślał, że możliwe są one wyłącznie dzięki ,jak" dzieła. A więc w jakiś sposób zostało ono wykonane (zorganizowane), generalnie - poziom tzw. formalny pozostaje związany „organicznie” z tym, co przez niego „prześwieca”. W rozmowie „Res Publiki Nowej” również zwrócono na tę kwestię uwagę. Mówił Adam Wiedemann:

Winni są nie artyści, tylko krytycy. Zafiksowali się na kryterium tematycznym. Ważny jest temat i jego społeczna doniosłość. Zarówno krytycy sztuki jak i krytycy muzyczni, a już zwłaszcza krytycy literaccy kierują się dziś kryterium tematycznym ${ }^{31}$.

Kto wie, czy nie jest to najpoważniejszy i najtrafniejszy zarzut, jeśli chodzi o aktualne funkcjonowanie krytyki literackiej, łączy się zapewne z masowością produkcji artystycznej, masowością propozycji. Im więcej pozostaje do przeczytania, tym bardziej starcza „średni poziom” (,brak czasu” na wsłuchanie się w odmienną do głębi „,konstrukcję pojedynczego głosu"), a reszty dokona taki lub inny temat, tak

$31 \quad$ Tamże, s. 98. 


\section{UTWÓR LITERACKI JAKO DZIEŁO SZTUKI}

czy inaczej rozwiązany, lepiej czy gorzej wpisujący się w nabrzmiałe spory i przepychanki społeczne, trendy światopoglądowe i rozmaitego rodzaju polityczno-społeczne alergie. Dzieło sztuki słowa staje się coraz bardziej elementem dyskursu, jakby wbrew sądom wcześniej przywoływanego Wiesława Juszczaka.

Mówi Tadeusz Sobolewski nieco wcześniej (co prawda odnosi się do wydarzenia z obszaru sztuk plastycznych, ale zasada zdaje się nie tylko tam obowiązywać):

Prasa broniła wolności artystki, chcąc zapobiec wymierzeniu jej kary za obrazę uczuć religijnych. Natomiast wielu z nas, dziennikarzy, miało $\mathrm{z}$ tego powodu kaca - że w imię słusznej sprawy wolności i tolerancji wszyscy ulegamy szantażowi, bronimy zwykłego głupstwa. Broniąc wolności sami sobie zakładamy knebel, nie mogąc się zdobyć na nieskrępowaną ocenę inkryminowanego dzieła. Zupełnie jak w czasach ,socu”, gdy „toczyła się ostra walka ideologiczna" i trzeba było w imię pokoju światowego, żeby nie wiem co, stać po stronie postępu, przeciw wstecznikom. W obawie przed atakiem sił ciemnogrodu nie mogliśmy w tym wypadku powiedzieć, że król jest nagi ${ }^{32}$.

Kryteria tematyczne świadczą też w istotny sposób o społecznej świadomości dzieła literackiego, w tym dzieła literackiego jako dzieła sztuki. Wyraźnie o bsuwają si ię wyróżniki - jakiekolwiek bądź ale wskazujące na sposób organizacji języka; w przypadku gatunków poetyckich - esencjalizacji języka.

Jednakże wyraźnie i najczęściej odczuwa się ich brak. Wydaje się, że powracające i w rozmowie „Znaku”, i dyskusji „Res Publiki Nowej" postawy, werbalizowane, ale też niewerbalizowane oczekiwania, jeśli wejrzeć w nie nieco uważniej, podważają wcześniejszą próbę hipotezy, dotyczącej „schizofreniczności” społecznych poglądów na sztukę.

\footnotetext{
32 Walka trwa.., dz. cyt., s. 43.
} 


\section{W PRZEKROJU, Z DYSTANSU...}

W tonacji zbliżonej, ale o jeszcze wyrazistszych konturach aksjologicznych, prowadzone są refleksje w „Ethosie” z 1997 r. (nr 40), wymownie zatytułowanym Sztuka na rozdrożu. Wypowiadają się w nim m.in. Bohdan Pociej i Stanisław Rodziński. Nie wiem, czy dałoby się przeprowadzić analogię między literaturą i muzyka, w każdym razie w odniesieniu do tej drugiej Bohdan Pociej stwierdza:

Muzyka poważna, powstająca dziś w obrębie świata cywilizacji zwanej niegdyś zachodnią, według mnie dzieli się czy rozpada na dwie zasadnicze strefy: w pierwszej działają [...] siły formotwórcze, w drugiej zaś czynniki rozkładające formę $e^{33}$.

Siły formotwórcze posiadają swe głębokie korzenie w tradycji europejskiej, rozkładające - napierają z innych stron. Wydaje się, że dla literatury podobne uogólnienie byłoby zbyt szerokie, straciłoby swoją zasadność. Chociaż, być może, refleksja krytyka muzycznego mogłaby stanowić rodzaj narzędzia (klucza) do porządkowania widzenia na obszarze zjawisk literackich.

Dominacja perspektywy tematycznej, komunikacyjno-społeczno-dyskursywnej, sytuowałaby się po stronie - wspominanych przez Pocieja - czynników rozkładających formę, chociaż w obu wcześniej analizowanych debatach rozpoznawalny jest opór i często skrywany protest przeciwko takiemu stanowi rzeczy.

Kondycja dzieła sztuki słowa (jego świadomości) daje się również wychwycić z rozmów prowadzonych na tematy pozornie odmienne. Stan rzeczy związany ze współczesną świadomością utworu literackiego odsłonił się wymownie w ostatniej, głośnej dyskusji „Tygodnika Powszechnego" (nry 22, 25, 27, 29, 30, 32, 35 w roku 2009). Przywołuję tę debatę, ponieważ mimo odmiennego tematu pierwszoplanowego tworzy ona znakomitą perspektywę dla obejrzenia interesującego mnie problemu. Debata polonistów o nauczaniu literatury staje się swego rodzaju źródłem wiedzy na temat: co stało się z rozumieniem, sposobem widzenia dzieła literackiego? Uczestniczyli w niej pracow-

33 Bohdan Pociej, Co się stało z muzykq w naszym stuleciu?, „Ethos” 1997, nr 40, s. 32. 
nicy naukowo-dydaktyczni polonistyk uniwersyteckich, ale też krytycy literaccy (m.in. Paweł Próchniak, Dariusz Nowacki, Piotr Śliwiński, Ryszard Nycz, Michał Paweł Markowski, Henryk Markiewicz). Jeśli postawimy pytanie: czym, dla dyskutantów, poza może (w pewnym stopniu i nie wprost) Pawłem Próchniakiem i Henrykiem Markiewiczem, jest utwór literacki, odpowiedzi wyłaniające się z tego marginalnego jakby dla dyskusji namysłu, okażą się nieco zaskakujące.

Wszak wydawałoby się, że filologia w ogóle (pierwotnie: „nauka o języku i jego zabytkach"34), a obecna krajowa filologia w szczególności, zwłaszcza w ciągu ostatniego wieku, stała się dyscypliną grupującą badaczy dzieł sztuki zmaterializowanych w języku; dyscypliną w pewien sposób analogiczną do historii sztuki na przykład, która bada i uczy rozumieć dzieła wyrażające się w językach sztuk plastycznych.

Dyskutanci mając w pamięci (powinni mieć) to wszystko, czego dokonano w XX w., a także wcześniej, w obrębie rozumienia języka ekspresji dzieła literackiego (i podstawowy fakt, że temat, przesłanie utworu - dzieła sztuki słowa - jest czymś innym niż ta sama myśl wygłoszona w ramach dyskursu poza dziełem), właściwie poruszali się po obrzeżach. Głos Dariusza Nowackiego ${ }^{35}$ - polemika podobno ze ,szlachetną wizją” Pawła Próchniaka, w zasadzie jest demonstracją przekonania, że o arcydziele literackim w realiach szkolnych (a może w ogóle?), zwłaszcza tym arcydziele z przeszłości nic już się nie da powiedzieć, bo wszystko zostało powiedziane („,doprawdy nie ma czego "scalać i rozumieć», bo wszystko już dawno zostało scalone i wyjaśnione" - chodzi o utwory Mickiewicza). Nawet jeśli weźmiemy pod uwagę, że dyskusja dotyczy polonistyki szkolnej, widoczna jest $\mathrm{w}$ tym podejściu jakaś całościowa degradacja pojęcia dzieła sztuki, które ze swej natury jest rezultatem procesu twórczego, a proces odbioru jest po prostu jego ponowną aktualizacją zakłada postawę twórcza, czego dyskutant Pawła Próchniaka (broniącego praktyki

34 Michał Głowiński, Filologia, hasło w: Michał Głowiński, Teresa Kostkiewiczowa, Aleksandra Okopień-Sławińska, Janusz Sławiński, Słownik terminów literackich, pod red. J. Sławińskiego, wyd. 3, poszerz. i popr., Wrocław 1998.

35 „Tygodnik Powszechny”, nr 25 (3128), 21 czerwca 2009. 
żywej interpretacji dzieła sztuki literackiej w szkole) zupełnie nie był w stanie zrozumieć.

Szczególnie wątpliwie (pozostaję przy ustalonej wcześniej perspektywie widzenia) brzmiały sądy Michała Pawła Markowskiego, $i$ te „suwerenne", i te sprowokowane krytycznymi uwagami Henryka Markiewicza. Markowski broni prawa studentów do odnajdywania w toku studiów problemów świata, w którym żyją, zagadnień skutecznie wpływających na możliwość samozrozumienia. I znów - pomija fakt osobności dzieła spełnionego. Do rozpoznania takiego utworu filologia polska powinna przecież dostarczać narzędzi. Markowski pisze:

Polonistyka winna być w pierwszym rzędzie szkołą wnikliwego czytania [na to zgoda B.K.-Ch.], niezależnie od tego, czy będzie się czytało Grocholę, czy Heideggera ${ }^{36}$

Ale Markowskiemu chodzi o dyskursywny typ lektury. Pomińmy fakt, że rozumienie Heideggera, samo w sobie bardzo korzystne dla każdego intelektu i dla każdej próby zrozumienia człowieka w świecie, domaga się przecież innej postawy, odmiennych sprawności percepcyjnych, aniżeli odbiór dzieła sztuki słowa. Co się stanie, jeśli młody adept literaturoznawstwa zatraci poczucie różnej jakości organizacji tekstu Grocholi i np. Chwina?

Oczywiście, cezura Gombrowicza tym bardziej powinna wyczulić tych, którzy są odpowiedzialni za literaturoznawcze kształcenie, na takie problemy jak np. proces twórczy, będący w pewien sposób analogonem rzeczywistego odbioru dzieła, uświadomić poszczególne fazy przeżycia estetycznego itd.; w sumie - przygotowywanie rzeczowej argumentacji na arcydzielność utworu. W „Tygodnikowej” dyskusji problem dzieła literackiego jako dzieła sztuki właściwie nie istnieje, nawet pośrednio, nawet bardzo pośrednio. Arcydzieło przeszkadza, jest co najwyżej drogą do „polonistycznego frazesu” - jak stwierdza jeden z rozmówców. Nikt tu nie mówi o błędach w nauczaniu, zły jest raczej przedmiot, o którym się mówi, więc, wedle niektórych

36 „Tygodnik Powszechny”, nr 35 (3138), 30 sierpnia 2009, s. 47. 
dyskutantów, może ten przedmiot należałoby wyeliminować (np. sonety Mickiewicza - bo o nie chodzi w tej wypowiedzi, wszak wiemy o Mickiewiczu już wszystko [sic!]).

Pisze Markowski krytycznie (mowa o obszarach zainteresowań literaturoznawców):

„Prawdziwi” poloniści wybuchają śmiechem, albo z politowaniem kręca głową na dźwięk słowa ,perwersja”, ale kiwają z uznaniem głowami, kiedy słyszą słowo „tradycja”. Tymczasem inaczej zgoła wygląda ta sama rzecz kilka pięter niżej: najzdolniejsi studenci chętniej mówią o perwersji [która pojawia się tu jako przykład] niż o tradycji, bo widzą jeszcze szanse związania zainteresowania literaturą z problemami, które obchodzą ich najbardziej: od egzystencji do polityki”37.

Może tak. Ale perwersja jako pewna krańcowość eksponowanego doświadczenia ludzkiego „zużywa”, zwłaszcza w zagęszczeniu (większej częstotliwości), możliwość spełnionej artystycznej ekspresji, domaga się skuteczniejszej „organizacji formy” - spójrzmy jak o perwersji pisze Faulkner; i kto jeszcze?

Tradycja natomiast, być może w ponawianych nieciekawych (tzn. mało odkrywczych) ujęciach akademickich nieco skostniała, ale $\mathrm{w}$ dalszym ciagu jest ważnym progiem w zdobywaniu narzędzi do pogłębionego, również najbardziej współczesnego dzieła, jego języka artystycznego wyrazu...

Generalnie uczestnicy tej wielkiej polemiki rozmawiają o kontekstach, tematach, modach; świadomość dzieła sztuki słowa, z nadzwyczajnością jego istnienia - organizacji, ekspresji, implikującego określone przeżycie estetyczne, gdzieś się zawieruszyła.

Interesujace rezultaty daje również lektura ostatnich numerów „Kwartalnika Artystycznego” (rok 2009), gdzie opublikowano głosy (często rozpisane, umotywowane) w ramach ankiety: Po przetomie - najważniejsze ksiażki dwudziestolecia. Michał Głowiński (nr 1, 2009) mówi o dziennikach intymnych, one zdominowały jego widzenie literatury ostatnich dziesięcioleci, ale charakterystyczne, że mówi

37 „Tygodnik Powszechny”, nr 32 (3135), 9 sierpnia 2009, s. 34. 
się tu m.in. o dziennikach Jarosława Iwaszkiewicza, Stefana Kisielewskiego; oczekiwanych: Mirona Białoszewskiego, Zygmunta Mycielskiego, Jana Józefa Lipskiego, Wiktora Woroszylskiego; czyli o dziennikach osób o ugruntowanej już pozycji (również literackiej) w świadomości społecznej.

W ogóle dla wypowiedzi z „Kwartalnika Artystycznego” znamienne jest, że raczej - takie wrażenie odnosi czytelnik - nie szuka się książek, nie „nadstawia ucha” (to byłaby sprawa ustawicznie aktualizowanych, szlifowanych kryteriów, dyskursu im poświęconego), a dowartościowuje tych autorów, którzy już zostali zweryfikowani. Jakby w sposób ostentacyjny, nie pisany, wzrastała trudność wyboru (lęk przed nim?).

Pojawiają się w ramach tej typologii m.in. Herbert (Elegia na odejście), Miłosz (To), Szymborska (Koniec i poczatek), a więc najczęściej nazwiska i książki bardzo znane, głównie dzięki mediom, prasowym kampaniom, czasami konkursom. Oczywiście, nie chodzi o to, że tomy przeze mnie przywołane nie zasługiwały na wytypowanie, ale bardziej o to, że nazwiska ,ugruntowane" są bezpieczne, pozwalają, być może, na skromniejszą, mniej radykalną pracę aparatu percepcyjnego.

Obecność klasyków, ,poetów starych” w typologiach „Kwartalnika Artystycznego" świadczy jeszcze o tęsknocie do tych norm estetycznych, które arcydzielność, w klasycznym rozumieniu tego słowa, potwierdzają. Z niechęcią mówi Ewa Sonnenberg o młodym pokoleniu literatów:

Pojawia się jakby nowy rodzaj poety i nowe podejście do tworzenia: liczy się tani efekt, by nie powiedzieć efekciarstwo, zabawy z inteligencją i beztroskie bagatelizowanie - oto klucze do bycia poetą w naszych czasach. [...] Zanika indywidualność, oryginalność, osobowość na rzecz tych samych postaw estetycznych, czyli kalkowanie wzajemnie swoich wierszy, metafor, pomysłów. Dwudziestolecie [ostatnie] to zwycięstwo przeciętności nad wielkością, przypadkowości nad celowością, przekłamań nad rzetelnością. [...] Przeinaczenie, zdeformowanie, wykręcenie, destrukcja i jest cool! Gdyby Gombrowicz to przeczuwał, pewnie inaczej zadysponowałby swoim talentem. [...] Tworzenie [...] to nie jakieś „pięć minut”, jak 
chciał Warhol, ale żmudne formułowanie, przeistaczanie, rozwijanie formy i treści. Tworzenie to rozpad i budowanie wciąż na nowo, na wyższym poziomie. Droga tworzenia jest jak kolejne etapy wtajemniczenia ${ }^{38}$.

Poprzez nostalgię tej wypowiedzi przebijają wyraziste, „twarde" kryteria. Bardzo stare; „indywidualność, oryginalność, osobowość” przypominają estetyczne dziewiętnastowieczne refleksje Stanisława Witkiewicza, który mówił o inteligencji, talencie i osobowości jako warunkach zaistnienia arcydzieła. Sonnenberg upomina się o dzieło jako świadectwo zmagania się z oporem materii twórczej.

Andrzej Zawada natomiast stwierdza: „Być może jednak, jak wiele symptomów na to wskazuje, rzeczywiście kończy się epoka Gutenberga, a wtedy literatura musi okazać się ginącym gatunkiem"39.

Jednak wypowiedzi z „Kwartalnika Artystycznego”, generalizując, w największym chyba stopniu odsłaniają świadomość utworu literackiego jako dzieła sztuki (w wypowiedziach poszczególnych jego świadomość zostaje werbalizowana) i tym również daje się wytłumaczyć mocną obecność np. „poetów starych” pośród tych głosów.

\section{PRÓBA UOGÓLNIEŃ}

Dzieło sztuki (mowa o zjawisku, pewnym fakcie, którego rozumienie pogłębiało się przez wieki i kolejne fazy kultury) jest w swoim „prapunkcie wyjścia” rezultatem doboru określonych elementów (fragmentów, części... itd.). Zatem podstawową czynnością tworzącego jest decyzja o zachowaniu lub odrzuceniu składników, które oferuje bogata rzeczywistość. Konstrukcja dzieła jest zatem konieczną hierarchizacją tych składników - ujmując rzecz możliwie prosto i elementarnie.

W dziele artystycznym kumulują się więc, ulegają wyjątkowemu zagęszczeniu (specyfikacji) czynności wyboru (doboru) i oceny. Najbardziej wyrazista jest ta podstawowa (wyjściowa) natura dzieła w przypadku sztuk muzycznych, ale przecież właściwa każdej dyscyplinie.

\footnotetext{
38 „Kwartalnik Artystyczny” 2009, nr 3, s. 125-126.

39 „Kwartalnik Artystyczny” 2009, nr 2, s. 147.
} 
Wydaje się, że dzieło sztuki, jeśli pamiętać o takiej jego „naturalnej” tkance, jej pochodzeniu, wchodzi w istotną kolizję z jakąś ,zasadą" współczesności: bezhieratycznością, bezhierarchicznością, amorficznością, zunifikowaniem, alergicznym uwrażliwieniem na autorytet. Kolizja, do jakiej dochodzi, nie jest zderzeniem z teoriami, przestrzenią zastrzeżoną dla wydarzeń o charakterze estetycznym. Jest fuzją, w której uczestniczy z jednej strony dzieło powstające w rezultacie niezmiennych, uniwersalnych aż po niewidoczność działań, z drugiej zaś ofensywna antropologia współczesności.

Dzieło sztuki literackiej w ciagu ostatnich dziesięcioleci jakby coraz mniej bywało dziełem sztuki, a w coraz większym stopniu miejscem wymiany myśli, społecznego dyskursu ${ }^{40}$.

Krytyka, co prawda sporadycznie, ale zdaje się dostrzegać ten problem i: albo przyjmuje medialną propozycję współczesności, również poprzez jej współtworzenie, albo zwraca się ku nostalgicznym rejonom rozmów o klasykach, ,poetach starych”, odnajdywaniu (próbom odnajdywania) w utworach najbardziej współczesnych ,perfekcyjnie wykonanej pracy, dzieła zamkniętego, skończonego, o wielkiej sile ekspresji".

Sądy uczestników przywoływanych debat sytuują się między przeświadczeniem, że coś się „obsuwa”, że właściwie nie do końca wiadomo, czym jest literackie dzieło sztuki, a elitarną, „wąską” pewnością, że zmieniło się niewiele, że przemiany i dyslokacje w coraz większym stopniu odsłaniają jakieś constans; widać to nawet w „,̇yczeniowym” trybie formowania uwag.

Ale jest to również krytyka nieco bojaźliwa, bywa, że doraźna problematyka społeczna (czy polityczna) osłabia i narusza jej świadomość estetyczna, poczucie kryteriów (nawet jeśli te kryteria traktować w sposób bardzo otwarty); często miękka, zmanipulowana przez siłę mediów, rozproszona przez nadmiar bodźców.

Może być też tak, że ta krytyka zdeterminowana nową wrażliwością na człowieka i poczuciem konieczności obrony jego praw nie umie jeszcze na poziomie właściwego sobie zaangażowania odczytać

\footnotetext{
40 Do podobnych wniosków, aczkolwiek od nieco odmiennej strony, dochodzi Maryla Hopfinger w szkicu Literatura między sztuka a komunikacja (tekst w druku).
} 
pewnych koniecznych warunków dyktowanych przez sztukę, pozornie skłóconych z nową jakością antropologiczną.

W fazie początkowych rekonstrukcji w tym szkicu, podczas analizy opisów najmłodszej poezji, wypłynął na marginesie problem możliwej opozycji: bardziej tradycyjne, ,elitarne” oczekiwania wobec dzieła sztuki spotykają się z żywiołem nowego chaosu, nowej powszechności. Jak każda niestabilna, rozwichrzona sytuacja, również i ta może stać się polem działania intensywnych, energetycznych działań twórczych. Stare konfiguracje zostaną przemienione w nową jakość. Historia banalnie się powtarza.

\section{Summary \\ Literary work as a piece of art (based on selected public discussions as noted down in Polish magazines after 1989)}

In the sketch the author raises the issue concerning the presence of a literary text in the contemporary social-media consciousness. At the outset the author draws two poles: the elite and egalitarian one, then, she passes to analysing public discourses which took place in the last century in cultural periodicals ("Znak", "Tygodnik Powszechny"). One of the crucial conclusions of her observations is the judgement according to which a literary masterpiece has been in the last centuries as if less a piece of art and become more a place of exchanging a thought and social discourse.

Transl. Joanna Stolarek 